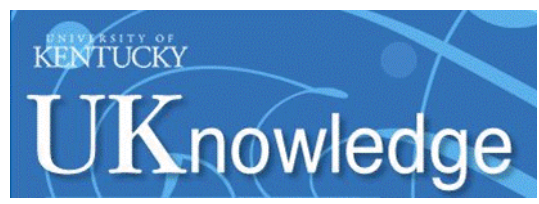

University of Kentucky

UKnowledge

$10-2019$

\title{
A Comprehensive Rehabilitation Program for Treating Lateral Elbow Tendinopathy
}

Joseph M. Day

University of Dayton

Ann M. Lucado

Mercer University

Timothy L. Uhl

University of Kentucky, tluhl2@uky.edu

Follow this and additional works at: https://uknowledge.uky.edu/rehabsci_facpub

Part of the Rehabilitation and Therapy Commons, and the Sports Medicine Commons

Right click to open a feedback form in a new tab to let us know how this document benefits you.

\section{Repository Citation}

Day, Joseph M.; Lucado, Ann M.; and Uhl, Timothy L., "A Comprehensive Rehabilitation Program for Treating Lateral Elbow Tendinopathy" (2019). Physical Therapy Faculty Publications. 111.

https://uknowledge.uky.edu/rehabsci_facpub/111

This Review is brought to you for free and open access by the Physical Therapy at UKnowledge. It has been accepted for inclusion in Physical Therapy Faculty Publications by an authorized administrator of UKnowledge. For more information, please contact UKnowledge@lsv.uky.edu. 


\section{A Comprehensive Rehabilitation Program for Treating Lateral Elbow Tendinopathy}

\section{Digital Object Identifier (DOI)}

https://doi.org/10.26603/ijspt20190818

\section{Notes/Citation Information}

Published in The International Journal of Sports Physical Therapy, v. 14, no. 5, p. 818-834.

(C) 2019 by the Sports Physical Therapy Section

The copyright holder has granted the permission for posting the article here. (Courtesy of the International Journal of Sports Physical Therapy) 


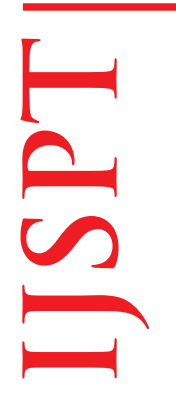

\title{
CLINICAL COMMENTARY \\ A COMPREHENSIVE REHABILITATION PROGRAM FOR TREATING LATERAL ELBOW TENDINOPATHY
}

\author{
Joseph M. Day, PT, PhD, OCS, CIMT \\ Ann M. Lucado, PT, PhD, CHT \\ Timothy L. Uhl, PT, ATC, PhD ${ }^{3}$
}

\begin{abstract}
Scapular muscle weakness in patients with lateral elbow tendinopathy is an identified impairment and is part of a multimodal rehabilitation approach. The published literature provides little information regarding specific rehabilitation guidelines that address both the proximal scapular muscle weakness and local elbow/ wrist dysfunctions common in patients with lateral elbow tendinopathy. The purpose of this clinical commentary is to describe a comprehensive rehabilitation strategy for individuals with lateral elbow tendinopathy. This program emphasizes a phased therapeutic strategy that addresses proximal and local dysfunction along the kinetic chain. This clinical protocol is currently being tested for efficacy as part of a randomized controlled trial. The information in this commentary is intended to provide clinicians with sufficient detail to comprehensively guide the rehabilitation of a patient with lateral elbow tendinopathy.
\end{abstract}

\section{Level of Evidence: 5}

Keywords: scapula, lateral epicondylitis, shoulder, lateral epicondylalgia, movement system

${ }^{1}$ Department of Physical Therapy, University of Dayton, Dayton, $\mathrm{OH}$

${ }^{2}$ Department of Physical Therapy, Mercer University, Atlanta, GA

${ }^{3}$ Department of Physical Therapy, University of Kentucky, Lexington, $\mathrm{KY}$

Declaration of Conflicting Interest: The Authors declare that there is no conflict of interest

Funding: This review received no specific grant from any funding agency in the public, commercial, or not-for-profit sectors.

\section{CORRESPONDING AUTHOR}

Joseph M. Day, PhD, MSPT, OCS, CIMT

Assistant Professor

Department of Physical Therapy

School of Education and Health Sciences

300 College Park Drive

University of Dayton

Dayton, OH 45469-2925

Phone: (937) 229-5621, Fax: (937) 229-5601

E-mail: jday01@udayton.edu 


\section{BACKGROUND AND PURPOSE}

Lateral elbow tendinopathy (LET) is the most common musculoskeletal elbow tissue injury and can result in significant limitations in function and decreased participation in activities. ${ }^{1}$ LET, lateral epicondylitis, or tennis elbow is defined as a pathology at or near the lateral epicondyle of the humerus resulting in pain, tenderness, and functional limitations. ${ }^{2}$ The mechanism of injury is variable but typically results from overloading of the common wrist extensors.

Clinically, LET can present acutely in the form of tendonitis, but more commonly presents chronically where degenerative tendon changes, disorganized collagen bundles, scar tissue, and hypervascularity has been identified. ${ }^{3}$ Risk factors for developing tendinopathy are both load related (biomechanical) and systemic. Known systemic risk factors include hypercholesterolemia, diabetes, hormonal imbalances, age and genetics. ${ }^{4,5}$ In general, systemic risk factors are thought to reduce the tendon capacity to manage load such that routine activities of daily living may be enough to trigger a pathological cycle. ${ }^{4}$

Although somewhat ambiguous, rehabilitation interventions are typically favored over medications, cortisone injections or surgery as the first method of treatment. ${ }^{6,7}$ When critically assessing the literature, best rehabilitation practice supports various forms of the therapeutic exercise and manual therapy for the immediate and short-term improvement in pain and function. ${ }^{8}$ Still, there is not a precise description of what constitutes an evidence-based multimodal treatment program for $\mathrm{LET}^{9}$ especially when it comes to preventing recurrence of the condition. ${ }^{10,11}$ Moreover, little guidance is available regarding the dosage (including the intensity, duration, frequency, and progression) of exercise prescription.

Recently, researchers have identified shoulder girdle weakness in patients with LET. ${ }^{12-14}$ Therefore, it is reasonable to assume that scapular muscle exercises should be considered as part of a comprehensive rehabilitation program for LET if weakness is present. One rationale for strengthening scapular muscles in this population is based on the Kinetic Chain Theory (KCT). The KCT proposes that during functional arm motions kinetic energy is transferred from proximal to more distal segments of the arm, providing an effective and efficient mode for distal function. ${ }^{15,16}$ As a result, proximal weakness increases the demand on the distal segment therefore overloading the distal segment. ${ }^{17}$ Without proper proximal scapular strength, there is an increased load on distal tissues at the elbow and wrist. ${ }^{18}$

Therefore, based on observational studies, expert opinion, and the KCT, scapular muscle performance could be an essential piece for rehabilitation professionals to address in patients with LET. However, no study has outlined a rehabilitation program for LET that includes scapular muscle exercises with sufficient detail for the purpose of clinical replication. Accordingly, the purpose of this clinical commentary is to describe a comprehensive rehabilitation strategy for individuals with lateral elbow tendinopathy. The provided rehab strategy will specifically include an evidence-based scapular stabilization algorithm integrated with a local treatment approach.

\section{DESCRIPTION OF THE PROGRAM}

The dual rehabilitation program (DRP) for LET is based on combining rehabilitation to two regions; the scapula and forearm (elbow/wrist). The DRP program utilizes therapeutic exercise, emphasizing a phased approach to scapular muscle and forearm strengthening, and local manual therapy techniques. The program was developed by clinicians and researchers with over 25 combined years of experience treating LET with special consideration given to the best evidence in the literature. This comprehensive rehabilitation program is currently being compared with a standard localized treatment approach in a multi-center randomized controlled trial (RCT). As part of the RCT, long term outcomes will be collected at six months and 1 year following discharge.

An overview of the program is provided in Table 1 , and more detailed information is found in the Appendices.

\section{ACTIVE WARM-UP}

The active warm-up can be chosen first as a means of increasing soft tissue temperature and enhancing muscle performance prior to performing therapeutic procedures. ${ }^{19}$ Moreover, short term aerobic 
Table 1. Overview of the Dual Rehabilitation Program

\begin{tabular}{|c|c|c|c|c|c|}
\hline Modality & Aim & $\begin{array}{c}\text { Therapeutic } \\
\text { Activity }\end{array}$ & Dosage/Load & Goals & Considerations \\
\hline Active Warm Up & $\begin{array}{l}\text { Increase blood flow, } \\
\text { soft tissue pliability, and } \\
\text { temperature. }\end{array}$ & $\begin{array}{l}\text { Treadmill walking } \\
\text { or } \\
\text { Upper body } \\
\text { ergometer (UBE) }\end{array}$ & $\begin{array}{l}<10 \text { minutes at } \\
\text { a comfortable } \\
\text { pace } \\
(2.0 \mathrm{mph} \text { on flat } \\
\text { incline })\end{array}$ & Up to 10 minutes & $\begin{array}{l}\text { Avoid UBE for those } \\
\text { with highly irritable } \\
\text { symptoms }\end{array}$ \\
\hline \multicolumn{6}{|l|}{$\begin{array}{l}\text { *Scapular Muscle } \\
\text { Matrix }\end{array}$} \\
\hline Phase 1 & $\begin{array}{l}\text { Neuromuscular re- } \\
\text { education of proximal } \\
\text { scapular stabilizing } \\
\text { muscles }\end{array}$ & $\begin{array}{l}\text { Unresisted or } \\
\text { isometric } \\
\text { activation of } \\
\text { serratus anterior } \\
\text { and middle/lower } \\
\text { trapezius muscles }\end{array}$ & $\begin{array}{l}\text { Work up to } 3 \\
\text { sets of } 10 \\
\text { repetitions } \\
\text { Once per day }\end{array}$ & $\begin{array}{l}\text { Isolate scapular } \\
\text { retraction/sternal } \\
\text { lift with correct } \\
\text { head posture from } \\
\text { a resting neutral } \\
\text { posture } 20 \text { times }\end{array}$ & $\begin{array}{l}\text { Avoid aggravation of } \\
\text { symptoms and } \\
\text { inappropriate muscle } \\
\text { substitutions }\end{array}$ \\
\hline Phase 2 & $\begin{array}{l}\text { Light to moderate } \\
\text { controlled stress for } \\
\text { progressive resisted } \\
\text { strengthening of } \\
\text { proximal scapular } \\
\text { stabilizing muscles }\end{array}$ & $\begin{array}{l}\text { Resisted exercises } \\
\text { for serratus } \\
\text { anterior and } \\
\text { middle/lower } \\
\text { trapezius muscle } \\
\text { groups }\end{array}$ & $\begin{array}{l}1-10 \text { lbs. } \\
\text { Work up to } 3 \\
\text { sets of } 10 \\
\text { repetitions } \\
\text { Once per day- } \\
\text { every other day }\end{array}$ & $\begin{array}{l}\text { Perform single } \\
\text { arm row with } 10 \\
\text { lbs. x } 20 \\
\text { repetitions without } \\
\text { pain, substitution } \\
\text { or increasing } \\
\text { symptoms } \\
\text { Perform single } \\
\text { arm push (punch) } \\
\text { with } 10 \text { lbs. from } \\
\text { waist to shoulder } \\
\text { level x } 1 \text { repetition }\end{array}$ & $\begin{array}{l}\text { When the patient is no } \\
\text { longer experiencing } 24- \\
\text { hour post onset muscle } \\
\text { soreness or their pain } \\
\text { does not increase }>1 \\
\text { level, advance resistance }\end{array}$ \\
\hline Phase 3 & $\begin{array}{l}\text { Moderate to heavy loads } \\
\text { with longer lever arms } \\
\text { for progressive resisted } \\
\text { strengthening of } \\
\text { proximal scapular } \\
\text { stabilizing muscles }\end{array}$ & $\begin{array}{l}\text { Advanced resisted } \\
\text { exercises for } \\
\text { serratus anterior } \\
\text { and middle/lower } \\
\text { trapezius muscle } \\
\text { groups }\end{array}$ & $\begin{array}{l}\text { Elongate lever } \\
\text { arm } \\
5-10 \text { lbs. } \\
\text { Work up to } 3 \\
\text { sets of } 10 \\
\text { repetitions } \\
\text { Every other day }\end{array}$ & $\begin{array}{l}\text { Independence } \\
\text { with advanced } \\
\text { strengthening } \\
\text { HEP without pain, } \\
\text { substitution or } \\
\text { increasing } \\
\text { symptoms }\end{array}$ & $\begin{array}{l}\text { Will typically need to } \\
\text { temporarily decrease } \\
\text { resistance when } \\
\text { advancing to Phase } 3 \\
\text { exercises with longer } \\
\text { lever arm }\end{array}$ \\
\hline \multicolumn{6}{|l|}{$\begin{array}{l}\text { *Wrist/Elbow Muscle } \\
\text { Matrix }\end{array}$} \\
\hline Phase 1 & $\begin{array}{l}\text { Neuromuscular re- } \\
\text { education of primarily } \\
\text { wrist extensors and } \\
\text { radial deviators }\end{array}$ & $\begin{array}{l}\text { Unresisted or } \\
\text { isometric } \\
\text { activation of wrist } \\
\text { musculature }\end{array}$ & $\begin{array}{l}\text { Work up to } 3 \\
\text { sets of } 10 \\
\text { repetitions } \\
\text { Once per day }\end{array}$ & $\begin{array}{l}\text { Perform AROM } \\
\text { and isometric } \\
\text { wrist extension } \\
\text { with no pain }\end{array}$ & $\begin{array}{l}\text { Avoid aggravation of } \\
\text { symptoms }\end{array}$ \\
\hline Phase 2 & $\begin{array}{l}\text { Light to moderate } \\
\text { controlled stress for } \\
\text { progressive resisted } \\
\text { strengthening of elbow } \\
\text { and wrist musculature }\end{array}$ & $\begin{array}{l}\text { Resisted exercises } \\
\text { for elbow and } \\
\text { wrist musculature }\end{array}$ & $\begin{array}{l}1-5 \text { lbs. } \\
\text { Work up to } 3 \\
\text { sets of } 10 \\
\text { repetitions } \\
\text { Once per day- } \\
\text { every other day }\end{array}$ & $\begin{array}{l}\text { Concentric/ } \\
\text { eccentric wrist } \\
\text { extension (elbow } \\
\text { flexed) with } 5 \mathrm{lbs} \text {. } \\
\text { x } 20 \text { repetitions } \\
\text { without } \\
\text { substitution or } \\
\text { increasing } \\
\text { symptoms }\end{array}$ & $\begin{array}{l}\text { When the patient is no } \\
\text { longer experiencing } 24- \\
\text { hour post onset muscle } \\
\text { soreness or their pain } \\
\text { does not increase }>1 \\
\text { level, advance resistance }\end{array}$ \\
\hline Phase 3 & $\begin{array}{l}\text { Moderate to heavy loads } \\
\text { with longer lever arms } \\
\text { for progressive resisted } \\
\text { strengthening of }\end{array}$ & $\begin{array}{l}\text { Advanced resisted } \\
\text { exercises for } \\
\text { elbow and wrist } \\
\text { musculature, } \\
\text { including } \\
\text { plyometric } \\
\text { exercises }\end{array}$ & $\begin{array}{l}\text { Elongate lever } \\
\text { arm } \\
\text { Work up to } 3 \\
\text { sets of } 10 \\
\text { repetitions } \\
\text { Every other day }\end{array}$ & $\begin{array}{l}\text { Independence } \\
\text { with advanced } \\
\text { strengthening } \\
\text { HEP without pain, } \\
\text { substitution or } \\
\text { increasing } \\
\text { symptoms }\end{array}$ & $\begin{array}{l}\text { Will typically need to } \\
\text { temporarily decrease } \\
\text { resistance when } \\
\text { advancing to phase } 3 \\
\text { exercises with longer } \\
\text { lever arm }\end{array}$ \\
\hline \multicolumn{6}{|l|}{ Education } \\
\hline $\begin{array}{l}\text { Patient Education and } \\
\text { Ergonomics }\end{array}$ & $\begin{array}{l}\text { Improve patient } \\
\text { understanding of } \\
\text { insulting activities and } \\
\text { how to modify tasks to } \\
\text { reduce damaging } \\
\text { stresses }\end{array}$ & $\begin{array}{l}\text { Ergonomic or } \\
\text { activity } \\
\text { assessment }\end{array}$ & & $\begin{array}{l}\text { Modify activities } \\
\text { to reduce } \\
\text { damaging stresses } \\
\text { and minimize } \\
\text { chances of } \\
\text { recurrent } \\
\text { symptoms }\end{array}$ & $\begin{array}{l}\text { Will be activity specific } \\
\text { May need sports specific } \\
\text { retraining }\end{array}$ \\
\hline
\end{tabular}




\begin{tabular}{|c|c|c|c|c|c|}
\hline Modality & Aim & Therapeutic & Dosage/Load & Goals & Considerations \\
\hline \multicolumn{6}{|l|}{ Local Manual Therapy } \\
\hline Elbow mobilization & $\begin{array}{l}\text { Stimulate } \\
\text { mechanoreceptors and } \\
\text { proprioceptors to } \\
\text { provide short term pain } \\
\text { relief and increased grip } \\
\text { strength. } \\
\end{array}$ & $\begin{array}{l}\text { MWM lateral } \\
\text { glide of the } \\
\text { ulna/radius on the } \\
\text { humerus }\end{array}$ & $\begin{array}{l}1 \text { bout } 6-10 \\
\text { repetitions } \\
\text { Up to } 3 \times \text { per } \\
\text { week } x 4 \text { weeks }\end{array}$ & $\begin{array}{l}\text { Pain relieve to } \\
\text { enhance tolerance } \\
\text { to exercise } \\
\text { progression }\end{array}$ & $\begin{array}{l}\text { Use lower grade } \\
\text { mobilizations for more } \\
\text { irritable symptoms }\end{array}$ \\
\hline \multicolumn{6}{|l|}{ Other Interventions } \\
\hline Wrist Extensor Stretches & $\begin{array}{l}\text { Increase muscle } \\
\text { flexibility and provide } \\
\text { short term pain } \\
\text { inhibition }\end{array}$ & $\begin{array}{l}\text { Elbow extended } \\
\text { with passive } \\
\text { stretch into wrist } \\
\text { flexion (with } \\
\text { simultaneous } \\
\text { pronation/digit } \\
\text { flexion) }\end{array}$ & $\begin{array}{l}30 \text { seconds } \\
\text { hold for } 3 \\
\text { repetitions } \\
3 \mathrm{x} / \text { day }\end{array}$ & $\begin{array}{l}\text { Pain free full } \\
\text { stretch of muscles } \\
\text { in posterior } \\
\text { compartment of } \\
\text { forearm }\end{array}$ & $\begin{array}{l}\text { May need to adapt the } \\
\text { stretch to accommodate } \\
\text { pain }\end{array}$ \\
\hline Counterforce Strap & $\begin{array}{l}\text { Off-loading of common } \\
\text { extensor tendon }\end{array}$ & $\begin{array}{l}\text { Strap placed about } \\
2 \text { fingers widths } \\
\text { below the painful } \\
\text { area and tension } \\
\text { adjusted to } \\
\text { comfort }\end{array}$ & $\begin{array}{l}\text { Wear while } \\
\text { performing } \\
\text { work, sports, or } \\
\text { potentially } \\
\text { aggravating } \\
\text { activity } \\
\text { Remove while } \\
\text { at rest and sleep }\end{array}$ & & 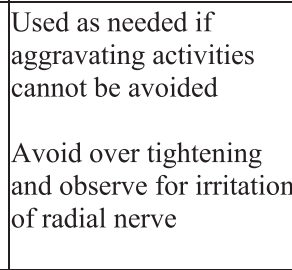 \\
\hline $\begin{array}{l}\text { Soft tissue } \\
\text { mobilization }\end{array}$ & $\begin{array}{l}\text { Enhance fibroblast } \\
\text { proliferation, collagen } \\
\text { synthesis and } \\
\text { organization. } \\
\text { Enhance blood flow }\end{array}$ & $\begin{array}{l}\text { Deep friction } \\
\text { massage or } \\
\text { myofascial release } \\
\text { of the common } \\
\text { wrist extensor } \\
\text { tendon. }(5 \mathrm{~min})\end{array}$ & 3-10 minutes & $\begin{array}{l}\text { Pain relieve to } \\
\text { enhance tolerance } \\
\text { to exercise } \\
\text { progression. } \\
\text { Potential increase } \\
\text { in range of motion }\end{array}$ & $\begin{array}{l}\text { Implement as needed } \\
\text { based on examination } \\
\text { findings }\end{array}$ \\
\hline Cryotherapy & $\begin{array}{l}\text { As needed to manage } \\
\text { pain and inflammation }\end{array}$ & $\begin{array}{l}\text { Cryotherapy } \\
\text { including ice pack } \\
(15 \text { min) or ice } \\
\text { massage }(5 \mathrm{~min})\end{array}$ & $\begin{array}{l}\text { As needed for } \\
\text { more irritable } \\
\text { symptoms or to } \\
\text { manage post } \\
\text { exercise pain } \\
\end{array}$ & & \\
\hline \multicolumn{6}{|c|}{ *For more detailed information on the scapular matrix and elbow/wrist matrix please refer to Appendices $A$ and } \\
\hline
\end{tabular}

exercises in conjunction with physical therapy has been shown to decrease pain sensitivity while also demonstrating improvements in health-related quality of life. ${ }^{20}$ Because patients often present with varying levels of elbow irritability, two warm-up options, treadmill and upper body ergometer (UBE), are recommended. Although the UBE is preferred, the treadmill can be utilized for patients in the acute phase of LET as a means of indirectly increasing the temperature of the common wrist extensors. In general, the warm-up procedure is no longer than 10 minutes for either the UBE and treadmill. The patients on the UBE are encouraged to cycle at a comfortable pace with no resistance applied. Patients on the treadmill can ambulate at $2.0 \mathrm{mph}$ on a flat incline.

\section{SCAPULAR MUSCLE STRENGTHENING MATRIX}

Based on several studies reporting EMG activity during specific scapular muscle exercises ${ }^{21-28}$ and modifications from a previous study, ${ }^{29}$ the authors established a progressive algorithm with three phases of strengthening: Phase 1 Neuromuscular education, Phase 2 Resistive with light to moderate loads/ short lever arm, and Phase 3 Resistive with moderate to heavy loads/ long lever arms. The exercises were specifically selected based on \% MVIC as well as exercises producing an optimal UT/LT ratios. ${ }^{30}$ For neuromuscular re-education (phase 1), others have recommended exercises in the range of $20-40 \%$ of MVIC. ${ }^{31,32}$ In general, exercises producing higher than $40 \%$ MVIC will induce a strengthening 
stimulus. ${ }^{33-35}$ Therefor, exercises in Phases 2 and 3 included those yielding 40\% or higher MVIC.

In regard to the scapula muscle exercises, Phase 1 has two options; isometric and isotonic exercises (including both concentric and eccentric phases of musculature contraction of the target muscles). Isotonic exercises are the preferred starting point, however if the patient experiences difficulty contracting the desired muscle, isometric exercises with visual and verbal feedback are prescribed by the therapist. Because the primary muscle groups addressing scapular stabilization are both the serratus anterior/ anterior musculature and middle/lower trapezius /posterior musculature, the anterior and posterior scapular exercises are separated. Figure 1 provides an example of an exercise progression in all three phases for both the posterior scapula. Please refer to Appendix A for the entire scapular muscle algorithm. As noted in the Appendix, there are several exercises from which to choose during each phase, and the patient's response will drive the exercise selection. Clinically, each patient will be at a different level, therefore, the authors agreed upon specific criteria to progress the patients from phase to phase in an orderly fashion.

\section{Progressions}

Phase 1 is instructed to all patients. The time to progress will vary and is based on specific criteria. In order to progress to Phase 2 the patient must demonstrate the ability to isolate scapular retraction/ sternal lift with correct head posture from a resting neutral posture 20 times in a row while standing in an upright posture without substitution or support and without aggravating symptoms. Each repetition must be held for a full five seconds for each repetition. To progress to Phase 3, patients must demonstrate that they can perform 20 repetitions with a set load of 10 lbs. without pain, substitution or increasing symptoms. A single arm row with 10 lbs. (black theraband cut $50 \mathrm{~cm}$ long) will generate 101bs at end of stretch for most people of heights between 5 and 6 feet. If the patient is over 6 feet tall, a $60 \mathrm{~cm}$ long TheraBand or use a cable column should be used. Also, the patient should be able to perform a single arm push (punch) with 10lbs from waist to shoulder level without pain, substitution or increasing symptoms.

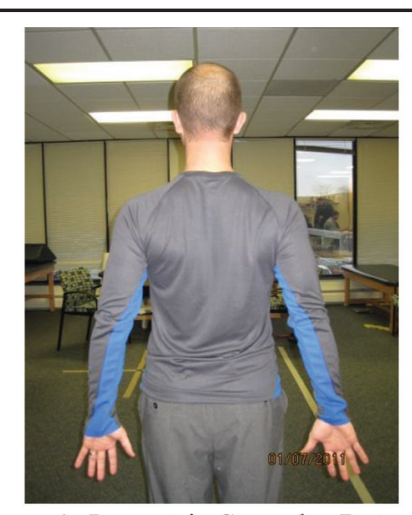

A. Phase 1: Isometric Scapular Retraction

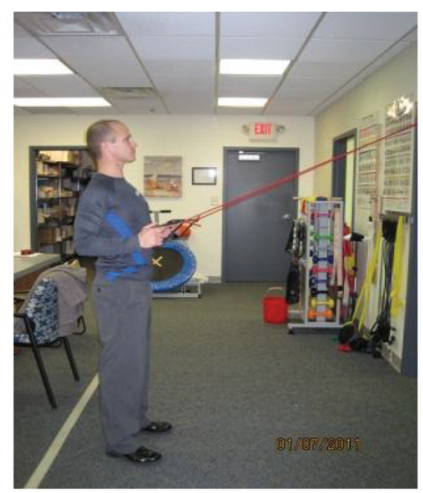

B. Phase 2: Elastic Resistance Rows with Elbows at Side

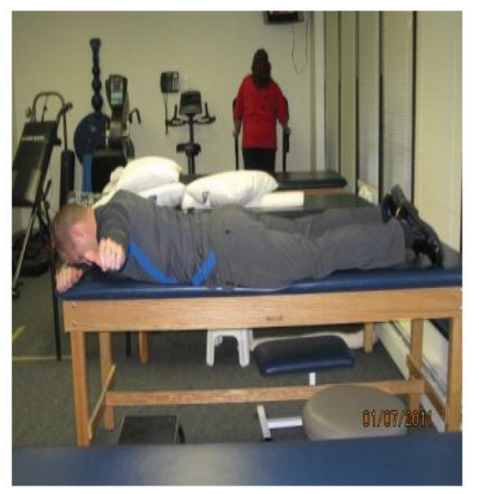

C. Phase 3: Prone Extension with/without Weight

Figure 1. Example of Scapular Muscle Strengthening Progression.

Refer to Appendix A for detailed exercise choices and performance instructions

\section{Repetitions and resistance}

Because the primary objective in the first phase is motor recruitment of the scapular muscles (serratus anterior, lower trapezius, rhomboids, and middle trapezius), the goal is to have the patient perform each exercise with no symptom reproduction and proper technique for three sets of $10 .^{36}$ After proper motor recruitment is achieved, the goal is to improve muscle strength and endurance. Therefore, the patient 
may perform up to three sets of 15 , with 60 seconds of rest between sets, within the second and third phases of this program. ${ }^{37}$ In all phases, the patient begins without weight and when the patient is no longer experiencing 24 hour post onset muscle soreness or the pain does not go up more than one level on the numeric pain rating scale (NPRS) (0-10), then resistance can be added. Accounting for individual variations in response to training, we also allow the patient to autoregulate reps, sets, or loads based on internal feedback. ${ }^{38}$

\section{WRIST AND ELBOW STRENGTHENING MATRIX}

Similar in form to the scapular muscle strengthening matrix, the authors designed three levels of strengthening for the wrist: Phase 1 Neuromuscular education, Phase 2 Resistive with light to moderate loads/ short lever arm, and Phase 3 Resistive with moderate to heavy loads/ long lever arms. (Figure 2, Appendix B). Neuromuscular education is positioned first for the purposes of muscle recruitment with a focus on isolating the muscle(s) in a controlled manner through isometric or isotonic contractions. Phase 2 focuses more on concentric and eccentric muscle activation patterns in a low load environment for the purpose of strengthening and building muscle endurance. Progressions from Phase 2 to Phase 3 were made using basic principles of loading; longer lever arms, increased weight bearing, increase in weight or resistance, and plyometric activities. The primary muscle groups that will be addressed for wrist and elbow strength are both the wrist extensors and the radial deviators and elbow flexors and extensors. The wrist and elbow program also includes flexibility within each phase to allow for differences in patient presentation and preferences.

\section{Progression}

Phase 1 is instructed to all patients, and the time to progress will vary and is based on specific criteria. To progress to Phase 2, the patient should be able to perform full wrist active range of motion and isometric wrist extension with no pain. To progress to Phase 3, the patient must demonstrate that they can perform 20 repetitions of concentric/eccentric wrist extension with the elbow flexed, forearm supported in pronation, and wrist over the edge of a supportive surface.

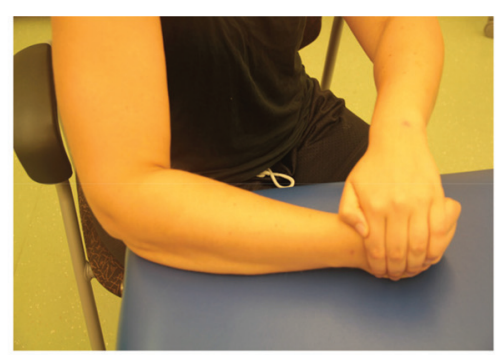

A. Phase 1: Short lever Isometric Wrist Extension

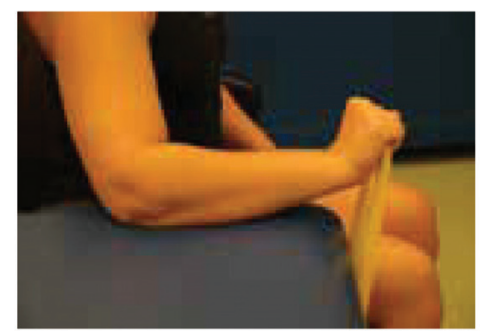

B. Phase 2: Short Lever Resisted Wrist Extension

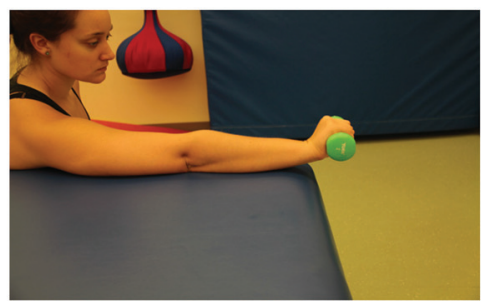

C. Phase 3: Long Lever Resisted Wrist Extension

Figure 2. Example of Wrist Extensor Strengthening Progression.

Refer to Appendix B for detailed exercise choices and performance instructions

Based on clinical experience, the patient should meet specific criteria before advancing to Phase 3. First, the patient performs 20 repetitions with a set load of 2 lbs. without pain, substitution or increasing symptoms before progressing to Phase 3. As an alternative, the patient could demonstrate a maximum effort grip strength that is no less than $80 \%$ of their age and sex matched normative data. ${ }^{39}$ The testing procedure should be performed in sitting with the shoulder in neutral, elbow flexed to $90^{\circ}$, and the wrist in neutral. ${ }^{40}$ The periodic testing of grip strength with a hand held dynamometer provides the therapist with objective data but also can enhance patient motivation during the rehabilitation process.

\section{Repetitions and resistance}

Similar to scapular muscle training, the goal in the first phase is to have the patient perform each 
Table 2. Thera Band Resistance Based on Color and Elongation.

Thera Band ${ }^{\mathrm{TM}}$

color

Resistance in pounds at $100 \%$ elongation

Resistance in pounds at $200 \%$ elongation

\begin{tabular}{|l|c|c|}
\hline Yellow & 3.0 & 4.3 \\
\hline Red & 3.7 & 5.5 \\
\hline Green & 4.6 & 6.7 \\
\hline Blue & 5.8 & 8.6 \\
\hline Black & 7.3 & 10.2 \\
\hline \multicolumn{2}{|c|}{ Source: http://www.theraband.com/products/resistance-bands-tubes.html }
\end{tabular}

exercise with no symptom reproduction and proper technique for three sets of 10. After proper motor recruitment is achieved, the goal is to improve muscle strength and endurance. Therefore, the patient can perform up to three sets of 15 , with 60 seconds of rest between sets, within the second and third phases of this program. ${ }^{37}$ In all phases, the patient begins without weight and when the patient is no longer experiencing 24 hour post onset muscle soreness or the pain does not go up more than one level on the numeric pain rating scale (NPRS) (0-10), then resistance can be added. Accounting for individual variations in response to training, the patient is allowed to autoregulate reps, sets, or loads based on internal feedback ${ }^{38}$ See Table 2 for a guide to resistance levels utilized with TheraBand.

\section{PATIENT EDUCATION AND HOME INSTRUCTION}

Rehabilitation experts generally consider patient education as a unique and critical piece to rehabilitation. Education is unique in that it is ongoing and critical because without proper patient understanding of the insulting activities, it is likely that the patient will relapse with the symptoms or cause a delay in healing time. More specifically, the literature supports ergonomic modifications ${ }^{41}$ and the following points of emphasis specific to tendonopathies: ${ }^{42}$

- Rest from activities that increase tendon loading and aggravate pain. The therapist will guide the patient in the proper loads and timing of those loads to ensure proper healing.

- Avoid repeated wrist, forearm or elbow movements. Do not avoid all upper limb motions as this will further reduce the tendons ability to take load.
- When exercising, make sure the exercises do not increase your pain as this might be a signal that the load is too much. Be particular mindfully of stretching.

- Use larger handles on utensils, tools, or tennis rackets

- Make modifications to your work area to promote good posture. The following should also be considered:

○ Don't maintain fixed postures for long periods of time. Consider setting a timer every 30 minutes to stand up.

$\circ$ A headset with microphone and dictation software

- A vertical mouse to promote a more neutral wrist posture

- Consult a trainer in your sport to help correct faulty mechanics or make appropriate adjustments in equipment

- Avoid palm down lifting; instead always try to lift with your palm up

- Avoid injections for pain management. Patients receiving multiple corticosteroid injections as a treatment modality typically fair worse in function and pain management in the long term.

\section{JOINT MOBILIZATIONS}

The primary aim of joint mobilization techniques in this population is to reduce or eliminate pain at the lateral epicondyle and improve range of motion at the elbow and wrist. A recent systematic review and meta-analysis found that mobilization with movement (MWM) techniques were effective at reducing pain and improving daily function up to three months after discharge in patients with LET. In general, the review also found that mobilizations were effective at reducing pain and improving grip strength as compared to controls. ${ }^{43}$

Based on the best evidence, the therapist is given the option to choose between three different techniques. ${ }^{44}$ The first two techniques are MWMs and involve a manual lateral glide of the ulna/radius by the therapist while stabilizing the humerus in a 
medial direction (Figure 3A). During the mobilization, the patient is asked to perform pain-free grip while holding isometrically for five seconds for 6-10 repetitions. The second technique involves the use of a mobilization belt using the same direction of force mentioned in the first technique, however the patient is asked to extend the elbow rather than sustain an isometric grip (Figure 3B). The third technique is an anterior glide of the radial head on the ulna (Figure 3C) with no active movement from the patient. The third technique is utilized if the patient does not respond to the first two techniques. Please see Appendix C for more information regarding joint mobilization techniques.

\section{OTHER INTERVENTIONS}

The interventions listed below (and also described in Table 1) are intended to be supplemental to the outlined program above. It is recommended that

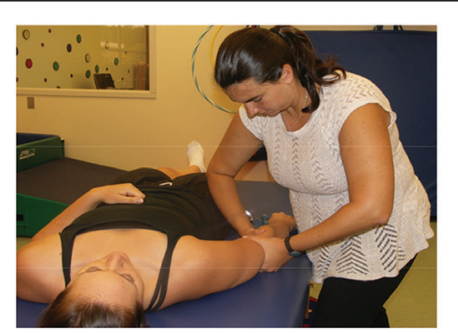

A. Sustained lateral glide of elbow with pain free grip

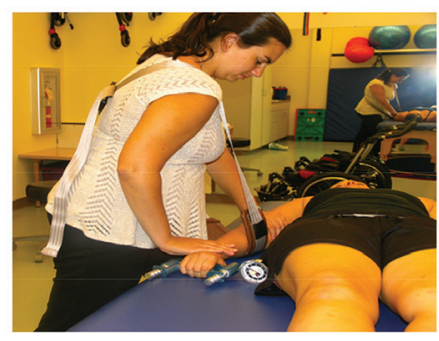

B. Sustained lateral glide of elbow with pain free grip (using mobilization belt)

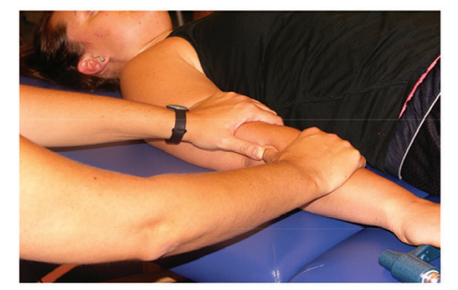

C. Radiohumeral joint sustained postero-anterior glide with pain free grip

Figure 3. Mobilization with Movement for the Elbow. Refer to Appendix $C$ for more detailed performance instructions all of the interventions listed below be addressed early in the plan of care as most of these agents will address pain directly and allow the patient to participate more fully in the exercise portion of the protocol which has been shown to be more effective for function in the long term. It is also up to the individual treating therapist to determine the need for such an intervention and how long to use the following interventions within an episode of care.

\section{Wrist extensor stretching}

All patients should be instructed in wrist extensor stretching. Even if there are no flexibility deficits, stretching can provide short-term pain inhibition when compared to no treatment. ${ }^{45}$ Caution should be exercised against aggressive stretching if the pain on palpation is insertional (i.e. potentially related to enthesopathy) where compressive loads (stretching) can be catabolic in nature resulting in a negative response to other interventions.

If the clinician opts for stretching, a judgement will have to be made in regard to how much tension to place on the wrist extensor mechanism. For example, if the patient presents with $>3 / 10$ pain during the Mill's sign, the clinician may opt to instruct the patient to stretch with the elbow flexed along with relaxing the index and middle fingers while only applying passive wrist flexion with the other hand. The previously described stretch will place less tension on the common wrist extensors when compared to a stretch where the elbow is placed in an extended position and the digits are maximally flexed. ${ }^{46}$ The authors propose performing stretches three times a day holding for 30 seconds and performing three repetitions during each session.

\section{Wrist Orthosis}

The literature supports the use of counterforce braces early in the rehabilitation process for improving pain pressure thresholds ${ }^{47}$ (Figure 4 ). The rationale for its efficacy is that the counterforce brace places tension on a more distal segment of the tendon or muscle while allowing healing time to the injured proximal insertion of the common wrist extensors. These straps may be of particular value to patients when eliminating the aggravating activity is not possible to allow for healing. For example, 


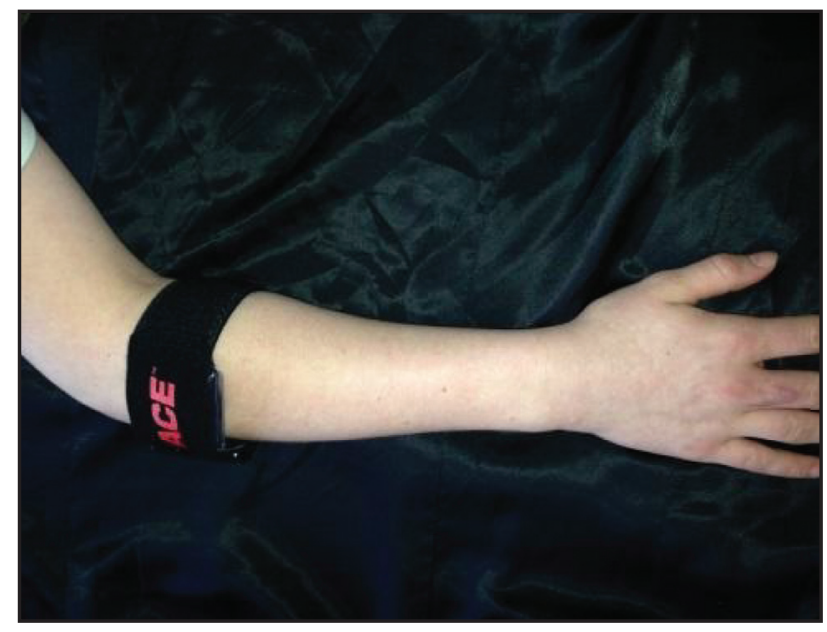

Figure 4. Lateral Elbow Tendinopathy Counterforce Brace.

high-level tennis players or individuals with manual labor jobs may not have the option to relinquish the activity in which case the counterforce brace is logically a good alternative.

The patients are instructed to use the counterforce strap during work and sports activities as needed, but not wear the strap while at rest. The strap should be placed about two finger widths below the painful area and the patients are instructed to adjust the tension to comfort while muscles are relaxed, and not to over tighten.

\section{Soft Tissue Mobilization}

For the purposes of reducing local pain, promoting tissue healing by increasing blood flow, and increasing tissue extensibility the treating therapist is given the option of performing a variety of soft tissue techniques. Deep friction massage (DFM) is typically performed in small circular movements across the common wrist extensor tendon. DFM is thought to assist the remodeling phase of an already degenerating tendon and to reduce scar tissue..$^{48}$ Alternatively, soft tissue massage along the common wrist extensor muscle belly could be chosen to promote relaxation and increase tissue extensibility. Finally, myofascial techniques addressing the common wrist extensors are applied to relieve pain and improve soft tissue extensibility. ${ }^{49}$ It should be noted that there is limited evidence to support the use of soft tissue techniques in treating tendinopathies. ${ }^{50}$ Consequently, the clinical decision to perform a specific soft tissue mobilization should be based on the finding of decreased elbow extension or decreased wrist flexion range of motion secondary to a common wrist extensor soft tissue restriction.

\section{Cryotherapy}

Cryotherapy may be effective in reducing local pain through a mechanism known as the gait control theory. ${ }^{51}$ In addition, cryotherapy causes vasoconstriction of superficial blood vessels and thus can reduce chemical pain that might be present. ${ }^{52}$ More specifically, ice massage has been shown to be effective as part of a multimodal program to treat tendinopathies, ${ }^{53}$ and it is recommended by the authors to be the clinician's first choice where it is not contraindicated. However, because ice massage involves a direct application of ice to the skin, individuals may not tolerate it as well. In this case, the clinician has the option of providing a homemade or commercial ice pack with one thin layer (typically a pillow case) to the lateral elbow after treatment in the clinic. ${ }^{54}$ Patients should also be instructed to perform cryotherapy at home and to apply the ice massage over the painful area for 3-5 minutes, especially after an aggravating activity. As an alternative, the patient is given the option to apply an ice pack to the elbow for 10 minutes up to 3-4 times a day to reduce pain.

\section{LIMITATIONS AND OTHER \\ CONSIDERATIONS}

Lateral elbow tendinopathy is often misdiagnosed. Although beyond the scope of this commentary, it is crucial that clinicians perform a proper medical screen and differential assessment prior to initiating the DRP. Common differential diagnosis for LET include cervical radiculopathy, radial tunnel syndrome, lateral collateral ligament pathology, radiocapitular osteoarthritis, fracture, triceps tendonitis, and referred pain from wrist injuries..$^{55}$ To that end, it is common for patients with LET to present with contaminant findings of cervical radiculopathy, radial nerve irritation, and intra-articular pain. ${ }^{56}$ Depending on the history, therapists may opt to perform tests such as resisted wrist supination (suggestive of entrapment of the posterior interosseous nerve along the supinator), ${ }^{56}$ Wainner's cluster for cervical radiculopathy (along with a neurological screening of $\mathrm{C} 6, \mathrm{C} 7),{ }^{57}$ and specific loading tests to target pathological intra-articular structures. ${ }^{58}$ 
Although the provided protocol is based on best available evidence, the authors acknowledge that the research regarding scapular muscle training for patients with LET is limited to observational studies only. However, research is only part of evidencebased practice and the authors contend that patient values and circumstances as well as clinical expertise are also valuable in designing a comprehensive rehabilitation protocol.

\section{CONCLUSIONS}

This clinical commentary outlines a regional and comprehensive rehabilitation program for patients with LET. The DRP emphasizes a three-phase scapular muscle and wrist extensor exercise program and joint mobilization while also suggesting other evidence-based interventions that could be of assistance. Based on individual presentations and response to treatment, the program is a flexible model through which effective and comprehensive treatment can be provided for patients with LET.

\section{REFERENCES}

1. Hume PA, Reid D, Edwards T. Epicondylar injury in sport: epidemiology, type, mechanisms, assessment, management and prevention. Sports Med. 2006; 36: $151-170$

2. Harrington JM, Carter JT, Birrell L, et al. Surveillance case definitions for work related upper limb pain syndromes. Occup Environ Med. 1998; 55: 264-271.

3. Cohen M, da Rocha Motta Filho G. Lateral epicondylitis of the elbow. Rev Bras Ortop. 2012; 47: 414-420.

4. Gaida JE, Cook JL. Risk factors for overuse tendinopathy. Australasian Musculoskeletal Medicine. 2008; 13: 60-65.

5. Abate M, Silbernagel KG, Siljeholm C, et al. Pathogenesis of tendinopathies: inflammation or degeneration? Arthritis Res Ther. 2009; 11: 235.

6. Bisset L, Paungmali A, Vicenzino B, et al. A systematic review and meta-analysis of clinical trials on physical interventions for lateral epicondylalgia. Br J Sports Med. 2005; 39: 411-422; discussion 411-422.

7. Segretin S, Cheriet S, Delarue Y. Rehabilitation and auto-exercises protocol in patients with chronic lateral epicondylitis: 6 months follow-up. Ann Phys Rehab Med. 2016; 59: 109-116.

8. Hoogvliet P, Randsdorp MS, Dingemanse R, et al. Does effectiveness of exercise therapy and mobilisation techniques offer guidance for the treatment of lateral and medial epicondylitis? A systematic review. Br J Sports Med. 2013; 47: 1112-1119.

9. Niedermeier SR, Crouser N, Speeckaert A, et al. A survey of fellowship-trained upper extremity surgeons on treatment of lateral epicondylitis. Hand (N Y). 2018: 1558944718770212.

10. Dingemanse R, Randsdorp M, Koes BW, et al. Evidence for the effectiveness of electrophysical modalities for treatment of medial and lateral epicondylitis: a systematic review. Br J Sports Med. 2014; 48: 957-965.

11. Nilsson P, Baigi A, Sward L, et al. Lateral epicondylalgia: a structured programme better than corticosteroids and NSAID. Scand J Occup Ther. 2012; 19: 404-410.

12. Day JM, Bush H, Nitz AJ, et al. Scapular muscle performance in individuals with lateral epicondylalgia. J Orthop Sports Phys Ther. 2015: 1-35.

13. Lucado AM, Kolber MJ, Cheng MS, et al. Upper extremity strength characteristics in female recreational tennis players with and without lateral epicondylalgia. J Orthop Sports Phys Ther. 2012; 42: 1025-1031.

14. Bhatt JB, Glaser R, Chavez A, et al. Middle and lower trapezius strengthening for the management of lateral epicondylalgia: a case report. J Orthop Sports Phys Ther. 2013; 43: 841-847.

15. Putnam CA. Sequential motions of body segments in striking and throwing skills: descriptions and explanations. J Biomech. 1993; 26 Suppl 1: 125-135.

16. Feltner ME, Bishop EJ, Perez CM. Segmental and kinetic contributions in vertical jumps performed with and without an arm swing. Res Q Exerc Sport. 2004; 75: 216-230.

17. Kreighbaurn E BK. Throwlike and pushlike movement patterns in biomechanics, a qualitative approach to studying human movement. 4th ed. Boston, MA: Allyn and Bacon, 1996.

18. Hidetomo S, Swanik KA, Huxel KC, et al. Alterations in upper extremity motion after scapular-muscle fatigue. Journal of Sport Rehabilitation. 2006; 15: 71-88.

19. Brunner-Ziegler S, Strasser B, Haber P. Comparison of metabolic and biomechanic responses to active vs. passive warm-up procedures before physical exercise. J Strength Cond Res. 2011; 25: 909-914.

20. Ote Karaca S, Demirsoy N, Gunendi Z. Effects of aerobic exercise on pain sensitivity, heart rate recovery, and health-related quality of life in patients with chronic musculoskeletal pain. International journal of rehabilitation research. 2017; 40: 164-170. 
21. Park SY, Yoo WG. Activation of the serratus anterior and upper trapezius in a population with winged and tipped scapulae during push-up-plus and diagonal shoulder-elevation. J Back Musculoskelet Rehabil. 2015; 28: 7-12.

22. Park KM, Cynn HS, Kwon OY, et al. Comparison of pectoralis major and serratus anterior muscle activities during different push-up plus exercises in subjects with and without scapular winging. $J$ Strength Cond Res. 2014; 28: 2546-2551.

23. Phadke V, Camargo P, Ludewig P. Scapular and rotator cuff muscle activity during arm elevation: A review of normal function and alterations with shoulder impingement. Rev Bras Fisioter. 2009; 13: 1-9.

24. Piraua AL, Pitangui AC, Silva JP, et al. Electromyographic analysis of the serratus anterior and trapezius muscles during push-ups on stable and unstable bases in subjects with scapular dyskinesis. J Electromyogr Kinesiol. 2014; 24: 675-681.

25. Pontillo M, Orishimo KF, Kremenic IJ, et al. Shoulder musculature activity and stabilization during upper extremity weight-bearing activities. $N$ Am J Sports Phys Ther. 2007; 2: 90-96.

26. Tsuruike M and Ellenbecker T. Serratus anterior and lower trapezius muscle activities during multi-joint isotonic scapular exercises and isometric contractions. J Athl Train. 2014.

27. Yoo WG. Effect of exercise speed and isokinetic feedback on the middle and lower serratus anterior muscles during push-up exercises. Journal of Physical Therapy Science. 2014; 26: 645-646.

28. Yoo WG. Effect of shoulder flexion angle and exercise resistance on the serratus anterior muscle activity during dynamic hug exercise. Journal of physical therapy science. 2016; 28: 278-279.

29. Day JM, Willoughby J, Pitts DG, et al. Outcomes following the conservative management of patients with non-radicular peripheral neuropathic pain. J Hand Ther. 2014; 27: 192-199; quiz 200.

30. Cools AM, Dewitte V, Lanszweert F, et al. Rehabilitation of scapular muscle balance: which exercises to prescribe? Am J Sports Med. 2007; 35: 1744-1751.

31. Chester R, Smith TO, Hooper L, et al. The impact of subacromial impingement syndrome on muscle activity patterns of the shoulder complex: a systematic review of electromyographic studies. BMC Musculoskelet Disord. 2010; 11: 45.

32. Barreto RPG, Robinson CC, dos Santos Rocha CS, MothesFC, Matsumoto F, da Rosa LHT, Silva MF. Lower trapezius and serratus anterior activation: which exercise to use for scapular neuromuscular reeducation. ConScientiae Saúde. 2012; 11: 660-667.
33. Decker MJ, Hintermeister RA, Faber KJ, et al. Serratus anterior muscle activity during selected rehabilitation exercises. Am J Sports Med. 1999; 27: 784-791.

34. De Mey K, Danneels L, Cagnie B, et al. Kinetic chain influences on upper and lower trapezius muscle activation during eight variations of a scapular retraction exercise in overhead athletes. Journal of Science and Medicine in Sport. 2013; 16: 65-70.

35. Escamilla RF, Yamashiro K, Paulos L, et al. Shoulder muscle activity and function in common shoulder rehabilitation exercises. Sports Med. 2009; 39: 663-685. .

36. Roy JS, Moffet H, Hebert LJ, et al. Effect of motor control and strengthening exercises on shoulder function in persons with impingement syndrome: a single-subject study design. Man Ther. 2009; 14: 180-188.

37. Bird SP, Tarpenning KM and Marino FE. Designing resistance training programmes to enhance muscular fitness: a review of the acute programme variables. Sports Med. 2005; 35: 841-851.

38. Mann JB, Thyfault JP, Ivey PA, et al. The effect of autoregulatory progressive resistance exercise vs. linear periodization on strength improvement in college athletes. J Strength Cond Res. 2010; 24: 1718-1723.

39. Peters MJ, van Nes SI, Vanhoutte EK, et al. Revised normative values for grip strength with the Jamar dynamometer. J Peripher Nerv Syst. 2011; 16: 47-50.

40. Hamilton A, Balnave R, Adams R. Grip strength testing reliability. J Hand Ther. 1994; 7: 163-170.

41. Goodman G, Kovach L, Fisher A, et al. Effective interventions for cumulative trauma disorders of the upper extremity in computer users: practice models based on systematic review. Work. 2012; 42: 153-172.

42. Cook JL. Ten treatments to avoid in patients with lower limb tendon pain. Br J Sports Med. 2018; 52: 882.

43. Lucado AM, Dale RB, Vincent J, et al. Do joint mobilizations assist in the recovery of lateral elbow tendinopathy? A systematic review and metaanalysis. J Hand Ther. 2018.

44. Vicenzino B. Lateral epicondylalgia: a musculoskeletal physiotherapy perspective. Man Ther. 2003; 8: 66-79.

45. Menta R, Randhawa K, Cote P, et al. The effectiveness of exercise for the management of musculoskeletal disorders and injuries of the elbow, forearm, wrist, and hand: a systematic review by the Ontario Protocol for Traffic Injury Management (OPTIMa) collaboration. J Manipulative Physiol Ther. 2015; 38: 507-520. 
46. Shirato R, Wada T, Aoki M, et al. Effect of simultaneous stretching of the wrist and finger extensors for lateral epicondylitis: a gross anatomical study of the tendinous origins of the extensor carpi radialis brevis and extensor digitorum communis. J Orthop Sci. 2015; 20: 1005-1011.

47. Borkholder CD, Hill VA, Fess EE. The efficacy of splinting for lateral epicondylitis: a systematic review. J Hand Ther. 2004; 17: 181-199.

48. Weerapong P, Hume PA, Kolt GS. The mechanisms of massage and effects on performance, muscle recovery and injury prevention. Sports Med. 2005; 35: 235-256.

49. Ajimsha MS, Al-Mudahka NR, Al-Madzhar JA. Effectiveness of myofascial release: systematic review of randomized controlled trials. J Bodyw Mov Ther. 2015; 19: 102-112.

50. Reinking M. Tendinopathy in athletes. Phys Ther Sport. 2012; 13: 3-10.

51. Ernst E, Fialka V. Ice freezes pain? A review of the clinical effectiveness of analgesic cold therapy.

J Pain Symptom Manage. 1994; 9: 56-59.

52. Christmas KM, Patik JC, Khoshnevis S, et al. Pronounced and sustained cutaneous vasoconstriction during and following cryotherapy treatment: Role of neurotransmitters released from sympathetic nerves. Microvasc Res. 2018; 115: 52-57.
53. Kedia M, Williams M, Jain L, et al. The effects of conventional physical therapy and eccentric strengthening for insertional achilles tendinopathy. Int J Sports Phys Ther. 2014; 9: 488-497.

54. Agostinucci JM, Cherry E. The effect of cryotherapy and exercise on lateral epicondylitis: a controlled randomised study. Int J Phys Ther Rehabil. 2012; 19: 641-650.

55. Ahmad Z, Siddiqui N, Malik SS, et al. Lateral epicondylitis: a review of pathology and management. Bone Joint J. 2013; 95-B: 1158-1164.

56. Faro F, Wolf JM. Lateral epicondylitis: review and current concepts. J Hand Surg Am. 2007; 32: 1271-1279.

57. Wainner RS, Fritz JM, Irrgang JJ, et al. Reliability and diagnostic accuracy of the clinical examination and patient self-report measures for cervical radiculopathy. Spine (Phila Pa 1976). 2003; 28: 52-62.

58. Sebelski CA. Current concepts of orthopaedic physical therapy. The elbow: physical therapy management utilizing current evidence. Independent study course, Orthopedic Section, American Physical Therapy Association, 2011. 


\section{APPENDIX A}

Scapular Muscle Strengthening Phase 1: Isometric Recruitment

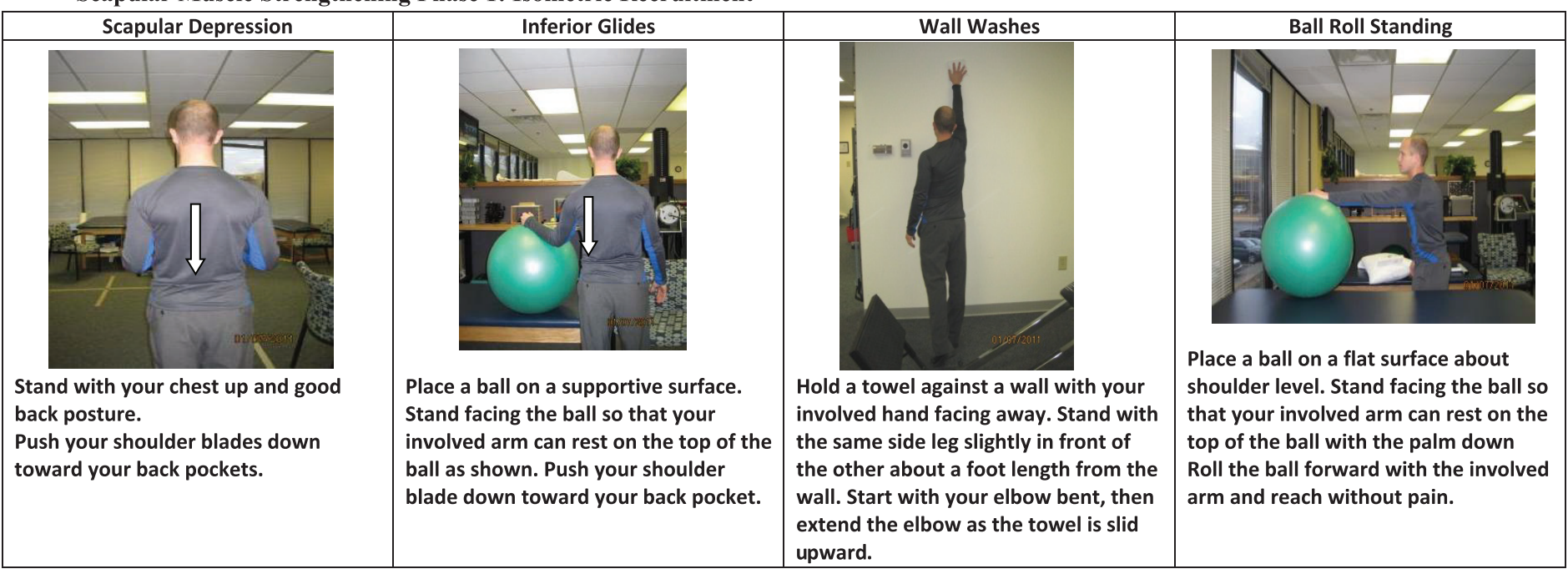

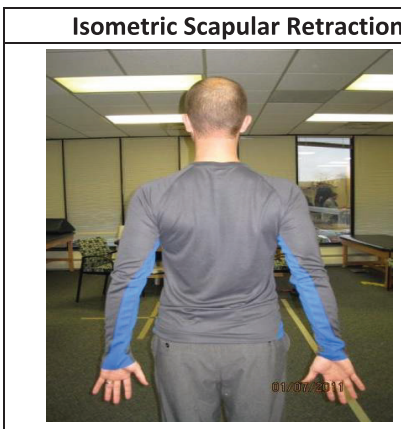

Stand with your chest up and good back posture, arms by your side, elbows straight. Squeeze your shoulder blades down and back as you bring both arms behind you.

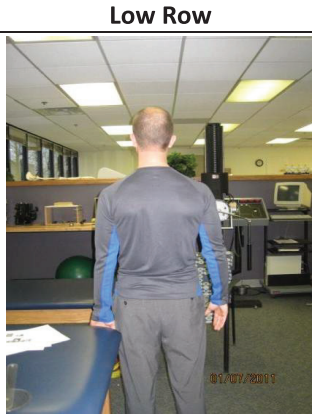

Stand in front of a supportive surface so that your involved hand can touch. Push your involved hand back against the surface while squeezing your shoulder blades together.

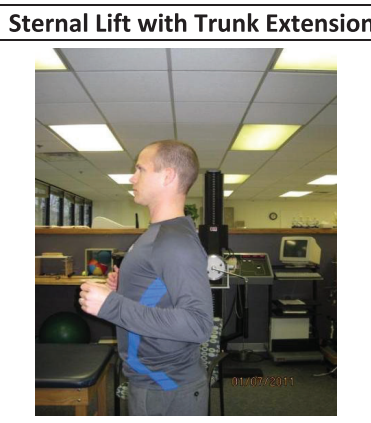

Stand with your arms by your side and elbows bent. Slightly lift your chest and at the same time squeeze your shoulder blades down and together.

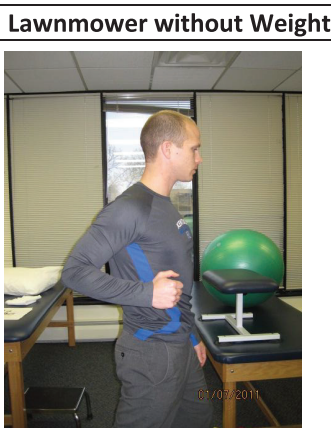

Reach forward with your involved arm while keeping good posture. Stand with the same side leg slightly behind the other. Pull the involved arm back (starting a lawnmower) and at the end squeeze your shoulder blades together.

*Choose 1 exercise from each row. The top row are exercises targeting the serratus anterior and the bottom row are exercises targeting the middle/lower trapezius. Hold times, sets, and repetitions will vary. 


\section{APPENDIX A (continued)}

Scapular Muscle Strengthening Phase 2: Light/Short Lever Arm

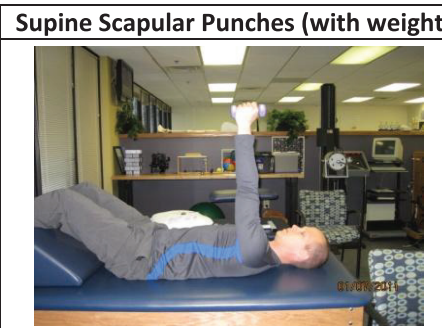

Lie on your back with the involved arm pointing straight to the ceiling. Without bending the elbow, punch your entire arm up toward the ceiling. Slowly rest the shoulder down.

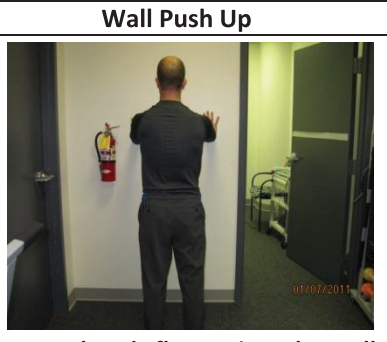

Place your hands flat against the wall. Bend your elbows, then push your body away from the wall as if doing a push up. When your elbows are straight, give an extra push way from the wall while separating your shoulder blades.
Elastic Resistance Punch with Step

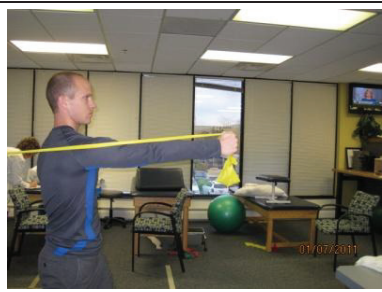

Stand holding a band with the involved arm pointing straight ahead. Punch forward, elbow straight, with the involved arm. If instructed, take a step forward with your opposite leg while punching.

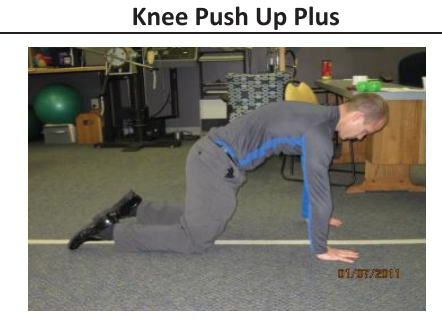

Begin on your hands and knees. Bend your elbows, then push your body away from the floor as if doing a push up. When your elbows are locked out, give an extra push way from the floor while separating your shoulder blades.

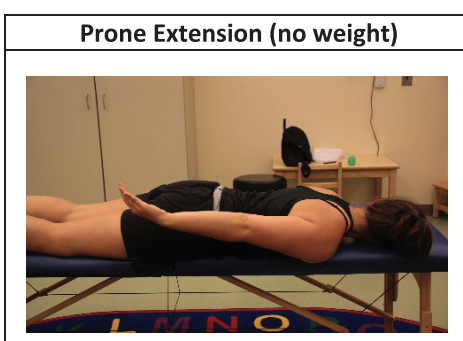

Lie on the edge of your bed with the involved arm hanging off. Bring the arm straight back with the palm facing down. Slowly lower it back to the starting position.

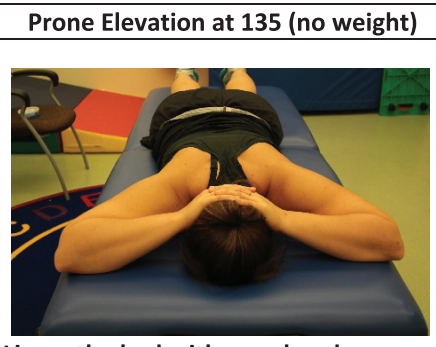

Lie on the bed with your hands clasped behind your head. Lift your elbows off of the bed (small movement) as you pull the shoulder blades together and down. Lower back to the starting position
Lawnmower with External Rotation

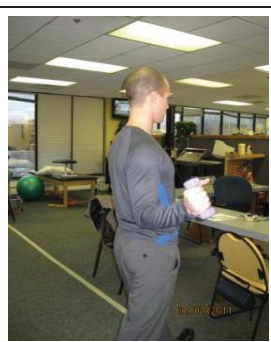

Reach forward with your involved arm while keeping good posture. Stand with the same side leg slightly behind the other. Pull the involved arm back (like starting a lawn mower) and at the end, rotate your forearm out and back while squeezing your shoulder blades.

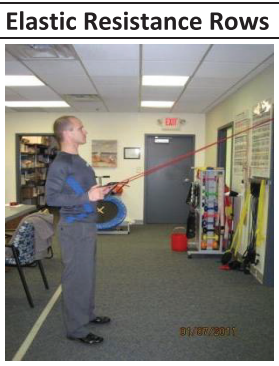

Attach a thera-band above doorway. Pull the band back with both arms, keeping the elbows bent. Squeeze the shoulder blades down and together at the end.

*Choose 1 exercise from each row. The top row are exercises targeting the serratus anterior and the bottom row are exercises targeting the middle/lower trapezius. Hold times, sets, loads and repetitions will vary. 


\section{APPENDIX A (continued)}

Scapular Muscle Strengthening Phase 3: Heavy/Long Lever Arm

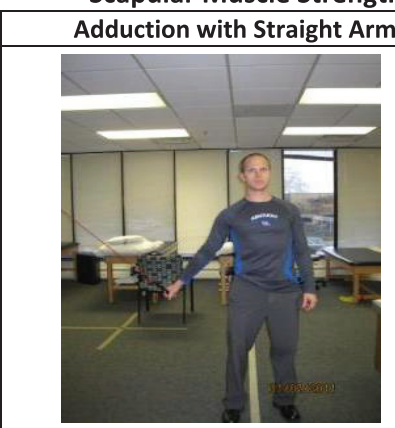

Attach a thera-band above the door. Begin by holding the band straight out about shoulder level. Pull the band straight down by your side while keeping the elbow straight while emphasizing scapular stability

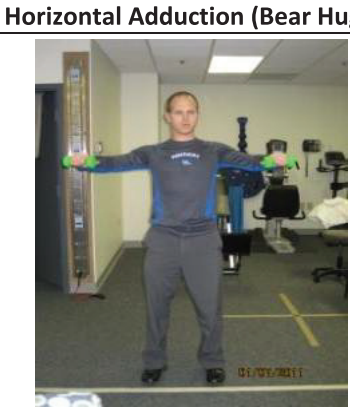

In the standing position, grasp two weights with the arms out to the side. Bring the weights together, keeping the elbows bent, as if giving a bear hug. Bring the arms back out to the starting position. (Begin with the thumbs up if the patient is experiencing symptoms.)

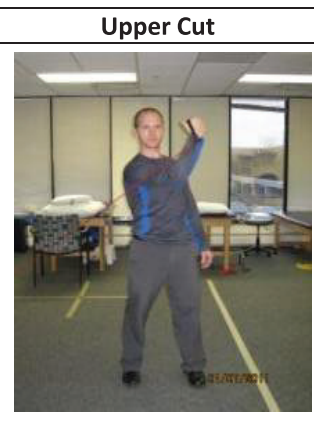

Place the band low in the doorway. Begin with your arm straight by your side. Pull the band across your body and up (upper cut). Slowly lower down to your side.

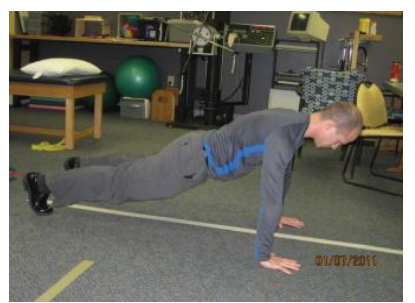

Begin in a plank position as shown. Bend your elbows, then push your body away from the floor as if doing a push up. When your elbows are locked out, give an extra push way from the floor while separating your shoulder blades.

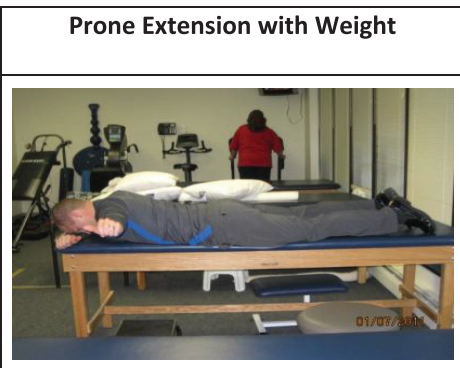

Lie on the edge of your bed with the involved arm hanging off. Bring the arm straight out to the side with the palm facing down. Slowly lower it back to the starting position.

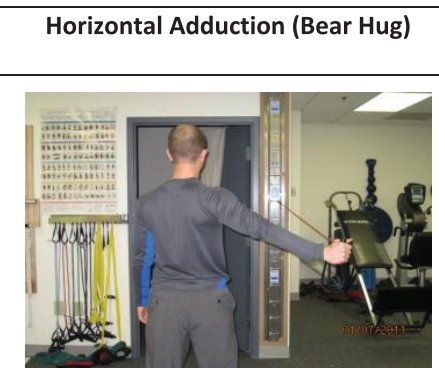

Place the band shoulder level in the doorway. Begin with your arm straight out at about $90^{\circ}$, and pull the band straight back with the involved hand. Slowly bring it back to the starting position.

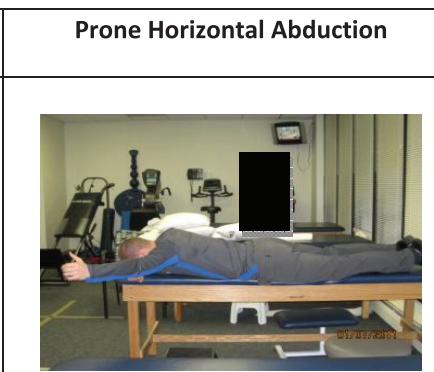

Lie on the edge of your bed with the involved arm hanging off. Bring the arm up at an angle while positioning the wrist so that the thumb is pointing up. Slowly lower it back to the starting position.
Horizontal Abduction with Elastic Resistance

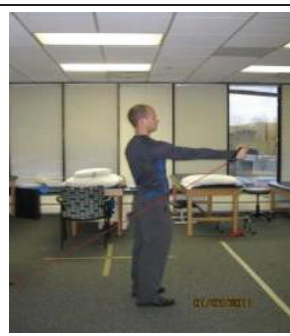

Place the band low in the doorway. Begin with your arm straight by your side. Pull the band straight up to shoulder level. Slowly bring it back to the starting position.

*Choose 1 exercise from each row. The top row are exercises targeting the serratus anterior and the bottom row are exercises targeting the middle/lower trapezius. Hold times, sets, loads and repetitions will vary. 


\section{APPENDIX B}

Wrist Strengthening Phase 1: Range of motion/isometrics

\begin{tabular}{|c|c|c|}
\hline Wrist motion- up and down & Wrist Motion - Side to Side & Stick twists \\
\hline $\begin{array}{l}\text { With your forearm palm down and wrist over the } \\
\text { edge of a table, bend your wrist forward and } \\
\text { back. }\end{array}$ & $\begin{array}{l}\text { With your forearm thumb up and wrist over the } \\
\text { edge of a table, move your wrist up and down. }\end{array}$ & $\begin{array}{l}\text { Hold stick or cane in both hands, twist upward } \\
\text { with affected hand (like a motorcycle throttle) }\end{array}$ \\
\hline Putty Squeezes & Wrist Isometrics- flexion & Wrist Isometrics- extension \\
\hline Gently squeeze putty into a fist. & $\begin{array}{l}\text { With your hand closed place your involved hand } \\
\text { palm down on the table. Press forward letting } \\
\text { the table resist your movement. }\end{array}$ & $\begin{array}{l}\text { With your hand in a close place your uninvolved } \\
\text { hand on the back side of your involved hand. } \\
\text { Resist backwards movement with the fingers of } \\
\text { your other hand. }\end{array}$ \\
\hline
\end{tabular}

*Choose 2-3 exercises from the available list. Hold times, sets, and repetitions will vary.

Wrist Strengthening Phase 2: light/short lever arm

\begin{tabular}{|c|c|c|}
\hline Twist stick with elbow extended & Resisted biceps curl (palm up) & Resisted biceps curl (thumb up) \\
\hline $\begin{array}{l}\text { Hold stick or cane in both hands, elbows straight } \\
\text { in front of you. Twist upward with affected hand } \\
\text { (like a motorcycle throttle). You may add a } \\
\text { string with a weight to make it more challenging. }\end{array}$ & $\begin{array}{l}\text { Stand with band in your hand, palm up. Step on } \\
\text { the other end to secure. Pull arm up toward your } \\
\text { shoulder and slowly lower. }\end{array}$ & $\begin{array}{l}\text { Stand with band in your hand, thumb up. Step } \\
\text { on the other end to secure. Pull arm up toward } \\
\text { your shoulder and slowly lower. }\end{array}$ \\
\hline Resisted biceps curl (palm down) & Resisted radial deviation (elbow bent) & Resisted extension (elbow bent) \\
\hline $\begin{array}{l}\text { Stand with band in your hand, palm down. Step } \\
\text { on the other end to secure. Pull arm up toward } \\
\text { your shoulder and slowly lower. }\end{array}$ & $\begin{array}{l}\text { Sit with band in your hand as shown. Step on } \\
\text { the other end to secure. Pull thumb/wrist up } \\
\text { toward ceiling and slowly lower. }\end{array}$ & $\begin{array}{l}\text { Sit with band in your hand as shown. Step on } \\
\text { the other end to secure. Pull wrist up toward } \\
\text { ceiling and slowly lower. }\end{array}$ \\
\hline
\end{tabular}

*Choose 2-3 exercises from the available list. Hold times, sets, loads and repetitions will vary.

Wrist Strengthening Phase 3: Heavy/long lever arm

\begin{tabular}{|l|l|l|l|}
\hline \multicolumn{1}{|c|}{ Prist Strengthening Phase 3: Heavy/long lever arm } \\
\hline $\begin{array}{l}\text { Resisted radial deviation (elbow wrist flips } \\
\text { straight) }\end{array}$ & Resisted extension (elbow straight) & Plyometric wrist snaps \\
$\begin{array}{l}\text { Sit with a ball in your hand, palm } \\
\text { up. Using one hand, toss up the } \\
\text { ball and catch it. As you get } \\
\text { better, you may try doing this with } \\
\text { a weighted ball. }\end{array}$ & $\begin{array}{l}\text { Sit with weight in your hand as } \\
\text { shown. Pull thumb/wrist up } \\
\text { toward ceiling and slowly lower. } \\
\text { (thera-band can replace weight) }\end{array}$ & $\begin{array}{l}\text { Sit with weight in your hand as } \\
\text { shown. Pull wrist up toward ceiling } \\
\text { and slowly lower. (thera-band can } \\
\text { replace weight) }\end{array}$ & $\begin{array}{l}\text { Sit with a ball in your hand, palm down. } \\
\text { Using one hand, toss the ball upward } \\
\text { and catch it. As you get better, you } \\
\text { may try doing this with a weighted ball }\end{array}$ \\
\hline
\end{tabular}

The International Journal of Sports Physical Therapy | Volume 14, Number 5 | October 2019 | Page 833 


\section{APPENDIX C}

\begin{tabular}{|c|c|c|c|}
\hline \multicolumn{4}{|c|}{ Mobilization with movement to the elbow } \\
\hline Mobilization: & $\begin{array}{l}\text { Sustained lateral glide } \\
\text { of elbow with pain free } \\
\text { grip }\end{array}$ & $\begin{array}{l}\text { Sustained lateral glide of } \\
\text { elbow with pain free grip } \\
\text { (using mobilization belt) }\end{array}$ & $\begin{array}{l}\text { Radiohumeral joint } \\
\text { sustained postero- } \\
\text { anterior glide with pain } \\
\text { free grip }\end{array}$ \\
\hline & & & \\
\hline Indication: & $\begin{array}{l}\text { Lateral elbow pain } \\
\text { increases with gripping }\end{array}$ & $\begin{array}{l}\text { Lateral elbow pain } \\
\text { increases with gripping }\end{array}$ & $\begin{array}{l}\text { Poor response to other } \\
\text { techniques }\end{array}$ \\
\hline $\begin{array}{l}\text { Position of } \\
\text { patient: }\end{array}$ & \multicolumn{3}{|c|}{$\begin{array}{l}\text { Supine, arm supported slightly abducted by side relaxed extension of elbow } \\
\text { forearm pronated }\end{array}$} \\
\hline $\begin{array}{l}\text { Position of } \\
\text { therapist: }\end{array}$ & \multicolumn{3}{|c|}{ Standing on the side of affected arm, facing the patient } \\
\hline $\begin{array}{l}\text { Stabilizing } \\
\text { hand: }\end{array}$ & $\begin{array}{l}\text { Heel and } 1^{\text {st }} \text { web space } \\
\text { on lateral surface of } \\
\text { distal humerus }\end{array}$ & $\begin{array}{l}\text { One hand stabilizes the } \\
\text { humerus and the other } \\
\text { maintains the position of } \\
\text { the forearm }\end{array}$ & $\begin{array}{l}\text { One hand stabilizes } \\
\text { distal humerus with } \\
\text { thumb over radial head }\end{array}$ \\
\hline $\begin{array}{l}\text { Mobilizing } \\
\text { hand: }\end{array}$ & $\begin{array}{l}1^{\text {st }} \text { and } 2^{\text {nd }} \text { digits on } \\
\text { medial surface of ulna } \\
\text { distal to joint line }\end{array}$ & $\begin{array}{l}\text { A belt can be used to } \\
\text { replicate the laterally } \\
\text { directed mobilizing force }\end{array}$ & $\begin{array}{l}\text { Other hand placed over } \\
\text { forearm with thumb } \\
\text { over thumb of } \\
\text { stabilizing hand }\end{array}$ \\
\hline Therapist: & $\begin{array}{l}\text { Apply laterally } \\
\text { mobilizing glide across } \\
\text { the elbow }\end{array}$ & $\begin{array}{l}\text { Apply laterally } \\
\text { mobilizing glide across } \\
\text { the elbow }\end{array}$ & $\begin{array}{l}\text { Apply postero-anterior } \\
\text { glide to the radio- } \\
\text { humeral joint }\end{array}$ \\
\hline Patient: & \multicolumn{3}{|c|}{ Repeats isometric gripping action until the onset of pain (but no more) } \\
\hline Repetitions: & \multicolumn{3}{|c|}{$6-10 \times$ per session } \\
\hline & \multicolumn{3}{|c|}{$\begin{array}{l}\text { Continue only as long as there is substantial relief of pain and no latent pain } \\
\text { immediately after the technique }\end{array}$} \\
\hline
\end{tabular}

